\title{
KEEFEKTIFAN MODEL PEMBELAJARAN WORD SQUARE BERBANTU MEDIA PUZZLE PADA MATA PELAJARAN IPS SD
}

\author{
Ibnatul Izzati $^{1)}$, Choirul Huda ${ }^{2)}$, Qoriati Mushafanah ${ }^{3)}$ \\ Universitas PGRI Semarang \\ e-mail: 1ibnaizzati1945@gmail.com; ${ }^{2}$ chairul.huda@gmail.com; ${ }^{3}$ Qoriati@gmail.com
}

\begin{abstract}
The problems of this research was: how the effectiveness of Word Square learning model supported by Puzzle media to improve learning outcome of Social subject of third grade at State Elementary School of Wonopringgo 01 (SDN 01 Wonopringgo). The type of this research was True Experiment Design with type of pretest-posttest control group design one kind of treatment. The samples were taken from students of the third grade of A SDN 01 Wonopringgo in the academic year 2016/2017. The data in this study was obtained through tests and documentation. Experimental research on the third grade of A which was given Word Square learning model supported by Puzzle media and the third grade of B was not given Word Square learning model supported by Puzzle media. Posttest results showed that the percentage of posttest grade of the experimental class was $95 \%$ of students expressed thoroughly, while the control class is $70 \%$, and based on t test one-party analysis obtained ttest $>$ ttable $=3,100816112>1.72$. Thus, it could be concluded that the learning with Word Square model supported by Puzzle media was effective against student learning outcomes in Social subjects (IPS) the third grade at SDN 01 Wonopringgo Pekalongan.
\end{abstract}

Keywords : effectiveness, word square, puzzle

\section{PENDAHULUAN}

Pendidikan mempunyai peranan yang penting untuk membantu siswa agar dapat berkembang secara optimal sesuai dengan kemampuan yang ada, serta memiliki kepribadian dan akhlak yang baik. Pendidikan juga memiliki tujuan yaitu untuk mengembangkan potensi peserta didik agar menjadi manusia yang beriman dan bertakwa kepada Tuhan Yang Maha Esa, berakhlak mulia, sehat, berilmu, cakap, kreatif, mandiri, dan menjadi warga Negara yang demokratis serta bertanggungjawab (UU No. 20 Tahun 2003 Bab II Pasal 3 Tentang Sistem Pendidikan Nasional). Namun pada kenyataannya, penerapan dari UndangUndang tersebut belum menampakkan hasil yang sebenarnya. Sebagian peserta didik masih merasa terbelenggu dengan pembelajaran konvensional yang menutup peserta didik untuk mengeksplorasi potensi yang dimiliki oleh peserta didik. Realita di lapangan, guru hanya bertindak sebagai penyampai materi sedangkan siswa selalu diminta untuk mencatat materi yang telah disampaikan oleh guru.

Penggunaan model pembelajaran kurang maksimal sehingga siswa merasa bosan saat mengikuti proses pembelajaran. Pembelajaran yang kurang maksimal ditandai dengan kurangnya minat minat peserta didik dalam mengikuti kegiatan belajar mengajar, seperti timbulnya rasa bosan dan mengobrol bersama temannya saat guru sedang menjelaskan materi.

Kondisi demikian sering terlihat dalam proses pembelajaran di Sekolah Dasar khususnya dalam pembelajaran mata pelajaran Ilmu Pengetahuan Sosial (IPS). Saat guru menyampaikan materi, kemudian peserta didik diminta untuk mencatat materi yang disampaikan oleh guru, sehingga sebagian 
besar peserta didik menganggap bahwa IPS adalah suatu pelajaran yang membosankan dan tidak tertarik untuk mengikuti proses pembelajaran yang sedang berlangsung. Padahal IPS mempunyai peranan penting dalam kehidupan sehari-hari bagi peserta didik. Oleh karena itu, pembelajaran konvensional diharapkan mengalami perubahan ke arah pembelajaran yang inovatif yang mampu melibatkan siswa agar mampu menarik perhatian, minat, serta menghilangkan kebosanan siswa pada saat proses pembelajaran IPS sehingga proses pembelajaran menjadi efektif. Pemahaman IPS, materi Uang dan Penggunaannya di SDN 01 Wonopringgo masih kurang. Hal ini terlihat dari nilai IPS materi Uang dan Penggunaannya yang belum optimal. Dari 20 peserta didik, terdapat 13 Peserta didik yang nilai IPS-nya belum mencapai Kriteria Ketuntasan Minimal (KKM), sedangkan selebihnya sudah mencapai KKM cukup optimal. Padahal KKM IPS dalam kelas 3 adalah 70 .

Tabel 1. Hasil Nilai Pretest IPS Materi Uang Dan

\begin{tabular}{ccccc}
\multicolumn{5}{c}{ Penggunaannya Kelas 3 } \\
\hline $\begin{array}{c}\text { Jumlah } \\
\text { Siswa }\end{array}$ & KKM & $\begin{array}{c}\text { Nilai } \\
\text { Rata- } \\
\text { Rata } \\
\text { Kelas }\end{array}$ & $\begin{array}{c}\text { Jumlah } \\
\text { Siswa } \\
\text { Tuntas }\end{array}$ & $\begin{array}{c}\text { Jumlah } \\
\text { Siswa } \\
\text { Tidak } \\
\text { Tuntas }\end{array}$ \\
\hline 20 & 70 & 69,50 & 7 & 13
\end{tabular}

Berdasarkan tabel 1 diketahui dengan jumlah peserta didik 20, terhitung nilai ratarata kelas IPS materi Uang dan Penggunaannya adalah 69,50. Nilai KKM di SD tersebut adalah 70, sedangkan berdasarkan tabel 1 diketahui bahwa masih terdapat 13 peserta didik yang nilainya belum mencapai KKM. Sedangkan 7 peserta didik mencapai KKM dengan nilai cukup optimal. Dari permasalahan tersebut, pembelajaran yang kurang menarik minat peserta didik perlu mengalami perubahan, salah satu perubahan yang bisa dilakukan adalah inovasi pada model pembelajaran. Model pembelajaran merupakan komponen yang penting dalam proses pembelajaran. Hal tersebut menjadi salah satu faktor penentu berhasil atau tidaknya suatu keberhasilan peserta didik. Saat ini banyak inovasi model pembelajaran yang diharapkan untuk menunjang proses pembelajaran.

Sesuai dengan tujuan untuk merubah proses pembelajaran menjadi aktif, inovatif, kreatif dan menyenangkan, maka perlu adanya model pembelajaran yang diharapkan sesuai dengan pembelajaran IPS harus dirancang oleh guru agar peserta didik merasa tertarik dengan IPS. Salah satu model pembelajaran yang dapat diterapkan adalah model pembelajaran Word Square berbantu media Puzzle.

Model pembelajaran Word Square merupakan model pembelajaran kooperatif yang memadukan kemampuan menjawab pertanyaan dengan kejelian dalam mencocokkan jawaban pada kotak-kotak jawaban. Model tersebut hampir sama dengan teka-teki silang, perbedaannya yaitu jawaban sudah ada dan disamarkan dengan menambahkan kotak tambahan berisi huruf sebagai pengecoh. Tujuan huruf pengecoh bukan untuk mempersulit siswa, namun melatih sikap teliti dan kritis.

Menurut Trianto (2014:53), bahwa model pembelajaran adalah kerangka konseptual yang melukiskan prosedur sistematik dalam mengorganisasikan pengalaman belajar untuk mencapai tujuan belajar tertentu, berfungsi sebagai pedoman bagi perancang pembelajaran dan para guru dalam merancang 
serta melaksanakan pembelajaran. Oleh karena itu, hal-hal yang harus diperhatikan ketika memilih model pembelajaran antara lain yaitu materi pelajaran, jam pelajaran, tingkat perkembangan kognitif siswa, lingkungan belajar dan fasilitas penunjang yang tersedia, sehingga tujuan pembelajaran yang telah ditetapkan dapat tercapai.

Model pembelajaran Word Square merupakan pengembangan dari metode ceramah dan termasuk salah satu model pembelajaran inovatif yang dapat memberikan inovasi pada proses pembelajaran. Model pembelajaran ini terdapat nuansa bermain didalamnya. Sejalan dengan realita tersebut, dalam penelitian Sukandheni et al (2014) dengan judul "Pengaruh Penerapan Model Pembelajaran Kooperatif Tipe Word Square berbasis Lingkungan Terhadap Hasil Belajar IPA Kelas V Gugus Budi Utomo Denpasar Timur" menunjukkan hasil belajar IPA siswa dengan menggunakan pembelajaran kooperatif tipe Word Square berbasis lingkungan pada siswa kelas V SDN 1 Kesiman sebagai kelompok eksperimen lebih baik dari hasil belajar IPA siswa yang menggunakan pembelajaran konvensional pada siswa kelas V SDN 8 Kesiman sebagai kelompok kontrol.

Selain itu, penelitian Muriana et al (2014) dengan judul "Pengaruh Model Pembelajaran Word Square Terdapat Hasil Belajar IPA Siswa Kelas IV SD Desa Tista Tahun Pelajaran 2013/2014" menunjukkan ada perbedaan yang signifikan dari hasil belajar IPA, antara siswa yang mengikuti pembelajaran dengan model pembelajaran Word Square dengan siswa yang mengikuti pembelajaran konvensional. Rata-rata hasil belajar kelompok eksperimen lebih besar dari rata-rata hasil belajar kelompok kontrol
$(34,80>28,44)$. Perbedaan yang signifikan menunjukkan bahwa penerapan model pembelajaran Word Square berpengaruh terhadap hasil belajar IPA siswa kelas IV SD Negeri Desa Tista.

Berdasarkan permasalahan yang telah diuraikan, maka peneliti ingin mengetahui keefektifan model pembelajaran Word Square berbantu media Puzzle untuk meningkatkan hasil belajar peserta didik kelas 3 SD Negeri 01 Wonopringgo Pekalongan, khususnya hasil belajar kognitif.

\section{METODE PENELITIAN}

Metode yang dipakai dalam penelitian ini adalah eksperimen. Menggunakan True Experiment Design (eksperimen yang betulbetul) dengan jenis pretest-posttest control group design satu macam perlakuan.

Menurut Arikunto (2013: 210), metode penelitian True Experiment Design (eksperimen yang betul-betul) dengan jenis pretest-posttest control group design satu macam perlakuan, sebelum dimulai perlakuan kedua kelompok diberi tes awal atau pretest untuk mengukur kondisi awal $\left(0_{1}\right)$. Selanjutnya pada kelompok eksperimen diberi perlakuan (X) dan pada kelompok pembanding tidak diberi. Setelah selesai perlakuan, kedua kelompok diberi tes lagi sebagai posttest $\left(\mathrm{O}_{2}\right)$.

Dalam penelitian ini, yang menjadi populasi adalah seluruh siswa kelas 3 SDN 01 Wonopringgo, Kecamatan Wonopringgo, Kabupaten Pekalongan. Sampel adalah bagian (anggota) dari populasi yang diambil secara benar (Soegeng, 2015:100). Sampel penelitian ini yakni seluruh siswa kelas 3 SDN 01 Wonopringgo, Kecamatan Wonopringgo, Kabupaten Pekalongan. Menurut Soegeng (2015: 105), teknik sampling merupakan teknik pengambilan sampel. Dalam penelitian 
ini, peneliti menggunakan teknik sampling nonprobability sampling yaitu sampling jenuh.

\section{HASIL PENELITIAN}

Hasil belajar merupakan perubahan berupa kecakapan fisik, mental, intelektual yang berproses dari kegiatan belajar baik di jenjang pendidikan formal seperti sekolah dan di jenjang pendidikan non formal seperti dilingkup keluarga dan masyarakat yang akan digunakan dalam kegiatan sehari-hari baik didalam sekolah maupun bermasyarakat (Ariyanto 2016:134). Dalam penelitian ini, hasil belajar yang dimaksud, terbatas berupa kecakapan intelektual saja yang diukur dari hasil tes formatif.

Berdasarkan analisis data yang telah dihitung dari uji t satu pihak, dapat diketahui bahwa hipotesisnya yaitu terdapat keefektifan model pembelajaran Word Square berbantu media Puzzle terhadap hasil belajar IPS materi uang dan penggunaannya pada siswa kelas 3 dengan $t_{\text {hitung }}>\mathrm{t}_{\text {tabel }}=3,100816112>1,72$. Data perhitungan uji $\mathrm{t}$ satu pihak juga diperkuat dengan hasil perhitungan uji n-gain, dengan hasil $n$-gain 0.42 di kelas kontrol dan 0.55 di kelas eksperimen.

Dengan demikian pembelajaran Word Square berbantu media Puzzle memberikan keefektifan terhadap hasil belajar peserta didik karena model pembelajaran Word Square berbantu media Puzzle adalah model pembelajaran yang menekankan pada keaktifan peserta didik selama proses pembelajaran.

Dari hasil uji $\mathrm{t}$ juga diperkuat oleh ketuntasan belajar kelas eksperimen yakni sebanyak 20 peserta didik mencapai ketuntasan belajar dengan presentase ketuntasan 95\% (19 siswa) dan nilai rata-rata
83,75. Sedangkan pada kelas kontrol hanya terdapat 14 peserta didik yang tuntas hasil belajarnya dengan presentase ketuntasan $70 \%$ dan nilai rata-rata 76 .

Adanya perbedaan presentase ketuntasan dan nilai rata-rata antara kelas eksperimen dan kelas kontrol disimpulan bahwa pembelajaran dengan model pembelajaran Word Square berbantu media Puzzle efektif untuk meningkatkan hasil belajar mata pelajaran IPS kelas 3 SDN 01 Wonopringgo. Hasil penelitian ini relevan dengan penelitian yang dilakukan oleh Sukandheni et al (2014) dan Muriana et al (2014) dengan hasil bahwa penerapan model pembelajaran Word Square dapat meningkatkan hasil belajar siswa di kelasnya.

Penggunaan model pembelajaran Word Square berbantu media Puzzle di kelas eksperimen menjadikan siswa lebih aktif, semangat dan antusias dalam mengikuti pembelajaran. Siswa juga tertarik dalam proses pembelajaran karena tidak hanya duduk memperhatikan guru ceramah dan mencatat materi yang disampaikan. Dibuktikan dengan kondisi siswa yang mengamati dan mencoba media Puzzle yang dibawa oleh peneliti, siswa berdiskusi, menyampaikan pendapat, mempertahankan pendapat serta bekerja sama dengan teman kelompoknya dalam memahami pembelajaran.

Sedangkan pada kelas kontrol yang menggunakan metode ceramah (pembelajaran konvensional) tanpa diberi model pembelajaran Word Square berbantu media Puzzle, ketika pembelajaran sedang berlangsung siswa hanya duduk dan mendengarkan guru menyampaikan materi (ceramah), sehingga siswa tampak bosan dan jenuh. Kedua perlakuan tersebut (kelas 
eksperimen dengan model pembelajaran Word Square berbantu media Puzzle dan kelas kontrol menggunakan pembelajaran konvensional) membawa dampak pada nilai siswa.

Dengan model pembelajaran Word Square yang membuat siswa dapat berdiskusi dan bekerja sama untuk memahami materi yang dipadukan dengan media Puzzle sudah tepat sesuai dengan materi, maka hasil pembelajaran menjadi meningkat lebih banyak daripada peningkatan hasil belajar pada kelas kontrol yang tidak menerapkan model pembelajaran Word Square berbantu media Puzzle.

Keberhasilan belajar pada kelas eksperimen ini tidak muncul begitu saja. Sekolah adalah salah satu faktor yang mendukung keberhasilan. Arti sekolah dalam hal ini bukan hanya gedung sekolah, tapi mencakup metode mengajar, relasi guru dengan siswa, pelajaran dan waktu sekolah, metode belajar, tugas rumah dan sebagainya. Keberhasilan belajar tentu saja tidak lepas dari model pembelajaran Word Square berbantu media Puzzle yang telah diterapakan oleh peneliti pada siswa kelas 3A SDN 01 Wonopringgo.

Karena dalam model pembelajaran Word Square berbantu media Puzzle terdapat banyak hal yang merangsang siswa untuk mendapatkan hasil belajar yang lebih baik daripada siswa yang tidak mendapatkan perlakuan model pembelajaran Word Square berbantu media Puzzle. Pada model pembelajaran Word Square ini siswa dijelaskan tentang materi, kemudian siswa membentuk kelompok yang beranggotakan 5 orang, setelah itu siswa mengamati dan menggunakan media, berdiskusi dan mendapat kuis serta soal evaluasi.
Diterapkannya model pembelajaran Word Square memberikan lebih banyak waktu kepada siswa untuk berdiskusi, bertukar pendapat dan bekerja sama dengan siswa lain, sehingga lebih percaya diri dan lebih mudah memahami materi yang disampaikan oleh guru. Sebelum mengerjakan soal evaluasi siswa juga dilatih dengan cara diberi kuis, sehingga hal ini membuat siswa semakin siap untuk mengerjakan soal evaluasi.

Pada saat pembelajaran, siswa sudah terlihat bersemangat mengikuti pembelajaran dan mengamati apa yang dibawa oleh guru. Pembagian kelompok dalam pembelajaran dilakukan secara acak, satu kelompok terdiri dari 5 orang.

Guru membagi kelompok secara homogen, melainkan secara heterogen (campur dengan berbagai jenis kelamin, suku, ras, dan agama). Hal ini dilakukan agar siswa mampu bekerja sama dengan siapapun. Penggunaan media Puzzle sebagai alat yang diamati, membuat siswa lebih mudah dalam berdiskusi, terdapat kelompok yang dapat memahami dan menemukan hasil diskusi secara cepat dan tepat.

Setelah selesai berdiskusi siswa diberi kuis dengan cara tebak-tebakan yang diberi oleh guru. Hal ini merupakan upaya untuk memperlihatkan hasil dari diskusi yang telah dilaksanakan dan sebagai latihan sebelum mengerjakan soal evaluasi. Rata-rata nilai tes sebelum perlakuan pada kelas eksperimen sebesar 70,25 dengan 9 siswa (45\%) yang dintayatakan tuntas dan 11 siswa (55\%) dinyatakan tidak tuntas. Setelah itu dilakukan pembelajaran dengan model pembelajaran Word Square berbantu media Puzzle diperoleh nilai rata-rata sebesar 83,74 dengan 19 siswa (95\%) siswa yang dinyatakan tuntas dan 1 siswa dinyatakan tidak tuntas. 
Jadi, kelas eksperimen dinyatakan tuntas secara klasikal (kriteria ketuntasan belajar klasikal adalah $80 \%$ ), presentase kenaikan hasil belajar siswa sebesar 50\%. Meningkatnya nilai rata-rata hasil belajar siswa dikarenakan perhatian siswa dalam proses pembelajaran menggunakan model pembelajaran Word Square berbatu media Puzzle.

Sedangkan pada kelas kontrol (yang tidak menggunakan model pembelajaran Word Square berbantu media Puzzle), rata-rata nilai tes sebelum diberik perlakuan pada kelas sebesar 69,50 dengan 7 siswa (35\%) yang dinyatakan tuntas dan 13 siswa (65\%) siswa dinyatakan tidak tuntas. Setelah dilakukan pembelajaran tanpa menggunakan model pembelajaran Word Square berbantu media Puzzle diperoleh nilai rata-rata sebesar 76 dengan 14 siswa (70\%) dinyatakan tuntas dan 6 siswa (30\%) dinyatakan tidak tuntas. Maka kelas kontrol dinyatakan tidak tuntas secara klasikal (kriteria ketuntasan belajar klasikal adalah $80 \%$ ).

Perbedaan hasil belajar siswa kelas kontrol dan kelas eksperimen ini dapat disebabkan karena perbedaan perlakuan dalam langkah-langkah pembelajaran. Hal ini terjadi karena proses dalam model pembelajaran Word Square membentuk siswa untuk menyelesaikan masalah secara berkelompok dan dapat bertukar pikian ketika berdiskusi serta dibantu media Puzzle yang memudahkan siswa untuk menyelesaikan masalah.

Selain itu, meningkatnya hasil belajar siswa dikarenakan siswa lebih antusias mengikuti pelajaran dengan model pembelajaran Word Square berbantu media Puzzle dan siswa menjadi lebih aktif saat pembelajaran berlangsung. Siswa juga tidak merasa bosan dan jenuh dalam pembelajaran karena siswa aktif dalam pembelajaran (berdiskusi, mengamati dan mencoba media Puzzle).

\section{SIMPULAN DAN SARAN}

Berdasarkan hasil penelitian yang telah dlaksanakan, dapat disimpulkan bahwa model pembelajaran Word Square berbantu media Puzzle efektif untuk meningkatkan hasil belajar IPS siswa kelas 3 SDN 01 Wonopringgo.

Ketuntasan belajar kelas yang dikenai model pembelajaran Word Square berbantu media Puzzle mencapai 95\% (lebih dari 80\%). Sedangkan kelas yang tidak dikenai model pembelajran Word Square berbantu media Puzzle ketuntasan belajar kelasnya hanya $70 \%$ (tidak lebih dari 80\%).

Berdasarkan simpulan di atas, saran yang dapat peneliti berikan yakni sebagai berikut:

a) Model pembelajaran Word Square berbantu media Puzzle dapat digunakan sebagai salah satu alternatif pembelajaran di sekolah, khususnya untuk materi dan tujuan pembelajaran yang sama.

b) Perlu penelitian lebih lanjut untuk menggunakan model pembelajaran Word Square berbantu media Puzzle untuk meningkatkan hasil belajar siswa pada materi atau mata pelajaran lainnya.

c) Model pembelajaran pembelajaran Word Square berbantu media Puzzle perlu diterapkan oleh guru dan terus dikembangkan pada pokok bahasan IPS lain sesuai dengan kebutuhan materi yang ada. Hal ini memungkinkan peserta didik merasa nyaman, senang, aktif, tidak bosan pada saat pembelajaran IPS yang selama ini dianggap oleh peserta didik 
sebagai pembelajaran yang membosankan.

d) Pada penelitian selanjutnya disarankan untuk melakukan uji validasi media Puzzle.

\section{DAFTAR PUSTAKA}

Arikunto, Suharsimi. 2013. Dasar-dasar Evaluasi Pendidikan. Jakarta: PT. Bumi Aksara.

Ariyanto, Metta. 2016. "Peningkatan Hasil Belajar IPA Materi Kenampakan Rupa

Bumi Menggunakan Model Scramble”. Jurnal Profesi Pendidikan Dasar. Vol. 3. No. 2, hlm. 133-141

Trianto. 2014. Model Pembelajaran Tepadu: Konsep, Strategi, dan Implementasinya Dalam Kurikulum Tingkat Satuan Pendidikan (KTSP). Jakarta: Bumi Aksara.

Trianto, IBA. 2014. Mendesain Model Pembelajaran Inovatif, Progresif, dan Kontekstual: Konsep, Landasan, dan Implementasinya pada Kurikulum 2013 (Kurikulum Tematik Integratif/TKI). Jakarta: Prenadamedia Group.

Soegeng. 2015. Dasar-dasar Penelitian: Bidang Sosial, Psikologi, dan Pendidikan. Yogyakarta: Magnum Pustaka Utama.

Sukandheni, L.P., et al. 2014. Pengaruh Penerapan Model Pembelajaran Kooperatif Tipe Word Square Berbasis Lingkungan Terhadap Hasil Belajar IPA Kelas V Gugus Budi Utomo Denpasar Timur: FIP Universitas Pendidikan Ganesha.

Muriana, DGA, et al. 2014. Pengaruh Model Pembelajaran Word Square Terhadap Hasil Belajar IPA Siswa Kelas IV SD Desa Tista Tahun Pelajaran 2013/2015. Denpasar Bali: Universitas Pendidikan Ganesha. 